\title{
Heracles in Homer and Apollonius: \\ Narratological Character Analysis in a Diachronic Perspective
}

\author{
Silvio Bär \\ Department of Philosophy, Classics, History of Art and Ideas, \\ University of Oslo, Norway
}

For Winnie

\section{Introduction}

Aristotle in his Poetics (1451a 16-22) mentions epics on the life and deeds of Heracles as a negative example of what he considers to be imperative for good dramatic progress and coherence, namely, the unity of action. ${ }^{1}$ According to Aristotle, unity of action is not automatically constituted by the sum of all the single events that occur in one and the same character's lifetime. This verdict encapsulates two parameters that are going to be of eminent importance in this article. First, it shows that Aristotle did not see an inherent connection between a literary character and the idea of unity, but indeed rather viewed these two aspects as contradictory. As will be demonstrated, plausible as it sounds, this methodological proposition is often not taken for granted in literary character studies in classical scholarship. Secondly, the Aristotelian passage testifies to the fact that Heracles was indeed popular as an

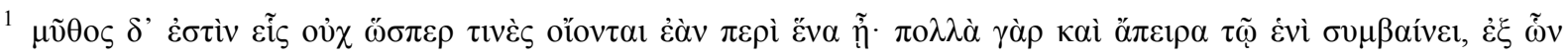

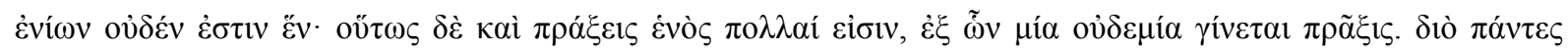

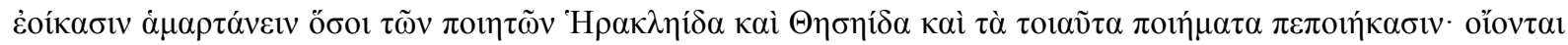

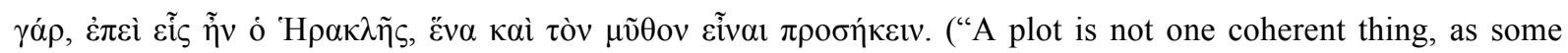
believe, if it is centred around one single [person]. For many, even countless [aspects] come together in one [person], the single parts of which do not constitute anything coherent. And similarly, the actions of one single [person] are many, from which no single action arises. Thus all those poets seem to miss the mark who have composed a Heracleis, a Theseis, and that sort of poems: for, they believe that, since Heracles was one individual [person], the plot must necessarily also be a coherent one.”) - The textual editions used in this article are: Tarán and Gutas (2012) for Aristotle's Poetics; van Thiel (1996) for the Iliad; van Thiel (1991) for the Odyssey; Vian and Delage (1974-1981) for Apollonius of Rhodes' Argonautica. All translations are my own.
} 
eponymous hero in numerous Greek epic poems from the Archaic Period onward. Unfortunately, though, with the exception of the pseudo-Hesiodic Aspis none of these epics survive. Notably enough, however, existing Greek epic poetry, ranging from Homer $(8 \mathrm{th} / 7$ th century B.C.) to Nonnus (5th century A.D.), always includes references to Heracles, be it on a diegetic or on a metadiegetic level. In what follows, I will offer a contrastive analysis of the character of Heracles in the Homeric epics the Iliad and the Odyssey, and in Apollonius of Rhodes' Argonautica. My analysis will be based on the methodological premises of narratological character analysis in a diachronic perspective, and with a cognitive take. It will be argued that Heracles serves specific narrative and metapoetic purposes in both Homer and Apollonius, and that the Heracles figure is particularly apt to serve these ends because of its decidedly multifaceted and in large parts contradictory nature.

\section{Narratological Character Analysis}

Until recently, narratological character analysis (henceforth: NCA) was only tangentially on the radar of narratologists operating within the field of Classics. This has changed in the past few years, in particular thanks to the recent publication of the volume Characterization in Ancient Greek Literature, the fourth in the Studies in Ancient Greek Narrative series (De Temmerman and van Emde Boas 2017a). ${ }^{2}$ However, groundbreaking and useful as this volume is, it is more concerned with classifying and describing the different types and techniques of characterization as they are employed in Ancient Greek narrative texts than with actually analysing specific characters from a narratological angle. ${ }^{3}$ Therefore, a few words about the theoretical concept and methods of NCA are necessary here. Essentially, the main tenet of NCA is the insight that, as Bal $\left({ }^{3} 2009,113\right)$ puts it, "the people with whom literature is concerned are not real people", but "creatures made up from fantasy, imitation, memory: paper people, without flesh and blood". However, as Bal continues, "the resemblance between human beings and fabricated figures is so great that we forget the fundamental difference: we even go so far as to identify with the character, to cry, to laugh, and to search for or with it, or even against it, when the character is a villain". Hence, in

\footnotetext{
${ }^{2}$ The editors' introduction in this volume provides a general overview of NCA in relation to Ancient Greek narrative texts (De Temmerman and van Emde Boas 2017b). A recent case study in this area is De Temmerman's (2014) monograph Crafting Characters: Heroes and Heroines in the Ancient Greek Novel.

${ }^{3}$ Cf. De Temmerman and van Emde Boas (2017b, 3): "we are interested in the textual devices used by ancient Greek authors for purposes of characterization, particularly when those devices can be ascribed to a narrator" (authors' emphasis).
} 
analogy to the concepts of intentional fallacy (viz., the readers' urge to attribute authorial intention to a literary text) and biographical fallacy (the tendency to derive information about an author's biography based on his/her writing), I suggest calling this hermeneutic problem the real life fallacy. That being said, it seems a truism to state that the overlap between artificially created characters and our mental concept of flesh-and-blood humans is a necessary precondition for literary characters to fulfil their function within the fictional world of a literary text (otherwise they would arguably lose their function as well as their appeal). Consequently, the real life fallacy must not simply be dismissed, but should instead be acknowledged and incorporated into a fully-fledged NCA.

Incorporating the real life fallacy into NCA basically calls for a cognitive approach. In his study Figur und Person: Beitrag zu einer historischen Narratologie (2004), Fotis Jannidis develops a cognitive definition of "character" based on prototype theory:

The prototype of a character is without doubt a human being, but numerous other creatures can be closer to, or more remote from, this prototype because of certain features and therefore can be identified as characters more or less easily. By way of intentional acting, especially by the use of language, as well as by the attribution of mental conditions, close proximity to the prototype and thus unambiguous classification as a character is achieved. ${ }^{4}$

It is evident why this definition is both appropriate and useful for the study of characters in ancient literature: with their massive population of gods, demons, monsters, etc. (for the most part taken from mythology, but taking pride of place in all forms and genres of literature), ancient narrative texts exhaust the possible range of human-like characters significantly more than modern literature does. In addition to this, Jannidis' cognitive definition facilitates the understanding of the hermeneutic problem that arises from the real life fallacy: for, it is only when we acknowledge that literary characters can deviate from the human prototype to some

\footnotetext{
4 Jannidis (2004, 114-115): "Der Prototyp einer Figur ist [...] ohne Zweifel ein Mensch, aber zahlreiche weitere Wesen können aufgrund bestimmter ihrer Merkmale mehr oder weniger entfernt von diesem Prototypen und entsprechend leicht oder weniger leicht als Figur zu identifizieren sein. Durch intentionales Handeln, besonders durch Sprachverwendung, sowie durch die Zuschreibung von psychischen Zuständen wird eine große Nähe zum Prototypen und damit eine eindeutige Klassifizierung als Figur erreicht." - Jannidis can be seen as a pioneer in cognitive literary studies. In the past few years, there has been a bold increase of cognitive approaches to literary studies and theory; cf. e.g. Wege (2013); Bruhn and Wehrs (2014); Cave (2016); Garratt (2016); Burke and Troscianko (2017); Müller-Wood (2017); Zunshine (2015). On cognitive humanities as a research trend, cf. e.g. Aldama (2015).
} 
(and, at times, considerable) extent that a succinct definition of "character" becomes possible - a definition that is inclusive, but does not simultaneously become arbitrary.

Another aspect that deserves consideration is that of transtextuality. A transtextual character is a character that is inherited from earlier tradition and/or from preceding texts - a character which, simply put, travels through literary history. Such characters "come with a set of pre-determined features, which both constrain the ways in which an author can represent them [...] and automatically steer their interpretation by readers" (De Temmerman and van Emde Boas 2017a, 5). Consequently, transtextual characters are diachronic and therefore require an approach that combines NCA with the study of intertextuality. Again, it is obvious that transtextual characters are legion in ancient literature because of the overwhelming presence of historical and mythological figures - and because of the decidedly intertextual nature of ancient literature, which is not, in the first place, concerned with innovation in terms of content, but, rather, with variation and rewriting of the same old stories. ${ }^{5}$

It seems evident that a figure such as Heracles is almost predestined to be analysed along those lines. First, he is one of the most complex and inconsistent figures in ancient mythology, and these "Heraclean paradoxes" (Feeney 1991, 95 n.134) are reflected - and functionalized - in different literary genres. To name only the most important and most outstanding of them, he is conceived as a "civilizer" who acts for the benefit of mankind - a characteristic which is present most prominently in his proverbial labours, the dodekathlos, where he fights against savage monsters and beasts, or in the story of the killing of the Egyptian king Busiris, which results in the cessation of human sacrifice (cf. Hdt. 2.45). In contrast, there is also an emphatically dark side to his character, as in Attic tragedy he is the type of the irascible Hercules furens who kills his wife and his children (cf. e.g. Euripides'

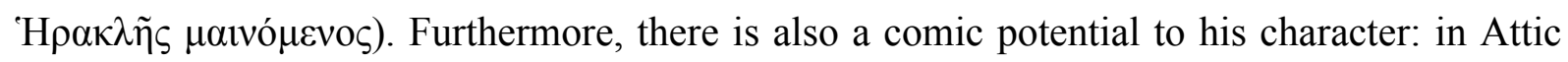
comedy as well as in the satyr play, he represents the type of the uncouth, simple-minded and gluttonous drunkard, the so-called Hercules comicus (cf. e.g. Euripides' Alcestis); a type that is, in turn, also akin to the more fairy-tale type of the strongman hero ("Starker Hans"). Finally, next to these emotional types, we can also find the intellectual and philosophical Heracles - best known from Prodicus' allegory of Heracles at the crossroads (cf. Xen. Mem. 2.1.21-34), and typologically important in the form of the abstentious Hercules Stoicus. ${ }^{6}$

\footnotetext{
5 To my knowledge, no systematic study on transtextual characters in ancient literature exists. On transtextual characters in modern literature, cf. Richardson (2010).

${ }^{6}$ Cf. Burkert $\left({ }^{2} 2011,319-324\right)$ for a survey. More in-depth treatments on most of these types are provided by Galinsky (1972) and Stafford (2012). On the philosophical Heracles, cf. also Stafford (2005). On Heracles in
} 
Secondly, the transtextual nature of Heracles is eminent. As just indicated, Heracles appears - and reappears - in various literary genres, and as far as Greek epic is concerned, he is incorporated, in one way or another, in all major epics from Homer to Nonnus (albeit never as a main character). Acknowledging that a literary character is a narrative construct and not the image of a flesh-and-blood person appears vital when we wish to understand a character as complex, inconsistent, and transtextual as Heracles. Furthermore, a cognitive approach to NCA, as offered by Jannidis, helps to understand that a multifaceted character such as Heracles can sometimes be closer, sometimes be more remote from the centre of the humancentred prototype, but that it can still count, and be perceived, as a literary character throughout literary history.

\section{Heracles in the Homeric Epics}

\subsection{Heracles in the Iliad}

Heracles was the main protagonist in many epic poems from the Archaic Period onward. However, apart from the pseudo-Hesiodic Aspis, none of these have survived except for a few fragments and summaries. ${ }^{7}$ The Homeric epics, in turn, also contain several references to Heracles. ${ }^{8}$ Heracles is evidently not part of the main narrative of the Iliad and the Odyssey since he belongs to an earlier generation of heroes; ${ }^{9}$ rather, the Heracles references are external analepses that serve as flashbacks to events that lie before, and beyond, the actual timeframe of the narrated time of the Homeric epics. In other words, Heracles in the Homeric epics forms part of what Grethlein $(2012,15)$ has called the "epic plupast", that is, "the

folk tale, cf. Heldmann (2000, 112-120); on the strongman character in fairy tale ("Starker Hans”), cf. Lox (2007).

${ }^{7}$ Fragmentarily preserved Heracles epics include Creophylus' The Capture of Oichalia, Pisander's Heraclea, and the Heraclea by Panyassis of Halicarnassus; cf. Huxley $(1969,99-112)$ and West $(2003,19-24)$ for an overview. Furthermore, cf. also Stesichorus' Geryoneus (fragmentary). The figure of Heracles and many of the myths surrounding him may be considerably older, perhaps even pre-Mycenaean (cf. Kirk 1973, 285-286).

${ }^{8}$ As do Hesiod's Theogony and the fragmentary Catalogue of Women. However, Hesiod's poetry will not be considered in this article. Cf. e.g. Mueller (2016) on Heracles in the Theogony, and Haubold (2005) on Heracles in the Catalogue of Women.

${ }^{9}$ Cf. Prinz $(1974,173-175)$ on the question as to whether Heracles is one or two generations older than the heroes of the Trojan War. The question is, in my opinion, only tangentially relevant; what is important is the fact that he is older than the generation of the present combatants, but still not too far away so as not to be remembered any longer. 
embedded past of the heroes [that] figures as a mirror to the heroic past presented in epic poetry". The following list provides an overview of all Heracles references in the Iliad, along with a brief summary of content:

2.653-670: The catalogue of ships mentions Tlepolemus, a son of Heracles. A short digression recounts how Heracles captured Tlepolemus' mother Astyocheia.

2.676-680: This passage mentions Pheidippus and Antiphus, two grandsons of Heracles, who participate in the Trojan enterprise.

5.381-404: Hera and Hades shot by Heracles are among the exempla of gods who were wounded by mortals, used by Dione to console her daughter Aphrodite who was injured by Diomedes in battle.

5.628-669: Tlepolemus (a son of Heracles and a grandson of Zeus) meets Sarpedon (a son of Zeus) in battle. Tlepolemus boasts his parentage by Heracles, and both heroes in their invectives allude to the first destruction of Troy by Heracles. Laomedon (Priam's father) had promised to award Heracles with his immortal horses if he was able to kill the sea monster that was threatening his daughter Hesione. Since Laomedon did not keep his promise, Heracles destroyed Troy.

8.357-369: Athena, talking to Hera, is irritated about Zeus because he weakens the Achaeans against her will. She mentions how she, in turn, used to assist Heracles during his dodekathlos on Zeus' behalf.

11.690-693: Nestor recounts to Patroclus how Heracles killed his eleven brothers when he was young, and how he was the only one to survive.

14.242-269: Hypnus (the god of Sleep) mentions the first destruction of Troy by Heracles: when Heracles sailed off, Hypnus put Zeus to sleep so that Hera could arouse a storm that brought Heracles (her intimate enemy) to the isle of Cos. Hypnus uses this incident as an argument as to why he should not enrage Zeus again, but Hera replies that Zeus' concern for his son Heracles was extraordinary.

14.312-316, 323-325: Zeus enumerates a catalogue of his extramarital affairs to Hera, which also include Alcmene, Heracles' mother.

15.24-30: After having woken up from the sleep induced by Hypnus, Zeus mentions the same incident that Hypnus mentioned towards Hera before (14.242269), that is, when she brought Heracles to the isle of Cos while he was asleep.

15.638-641: Hector kills Periphetes, a son of Copreus. Copreus is mentioned as Eurystheus' messenger who used to inform Heracles about his assignments. 
18.114-121: Achilles, announcing his intention to kill Hector and thus accepting his own death, mentions Heracles as a parallel who had to die too, although he was Zeus' favourite son.

19.91-138: Agamemnon recounts the story of Hera who induced the premature birth of Heracles' half-brother Eurystheus who, thanks to his primogeniture, was granted limitless might (instead of Heracles whom Zeus actually had had in mind when he gave his promise). Agamemnon uses the story as a mythical exemplum to demonstrate how powerful infatuation (ő $\tau \eta)$ can be. By doing so, he attempts to justify his own previous behaviour towards Achilles.

20.144-148: The primary narrator mentions the walls of Troy that gave shelter to Heracles when he fled from the sea monster that threatened Hesione and that he was commissioned to kill.

Based on these references, neoanalysis has been trying hard to reconstruct the possible scope and content of what arguably might have amounted to a "Heraclean cycle" analogous to the so-called "Epic cycle". ${ }^{10}$ The results of this strand of research are as fascinating as they are speculative, but they do not contribute to the overall understanding of the narrative function of any of these references within the Homeric epics. In what follows, I will attempt to demonstrate that in the Iliad, they serve a specific narrative and metapoetic end, and that the Odyssey subsequently responds to this function by reversing it.

As the above list reveals, references to Heracles are to be found dispersed over the entire Iliad - notably, in Books 2, 5, 8, 11, 14, 15, 18, 19, and 20. Thus, it appears that the character of Heracles should be recalled in the reader's mind on a regular basis - in other words: Heracles is meant to be (or, to become) part of what I call the reader's "epic memory", that is, his/her horizon of knowledge about the epic past and the epic world. ${ }^{11}$ The first mention fulfils exactly that purpose: reminding the audience of the greatest Greek hero in the context of the panhellenic catalogue of ships is particularly apt to establish the idea of some sort of national hero avant la lettre, and mentioning Heracles as the father and grandfather of three of the combatants from the current generation of heroes makes it abundantly clear that Heracles does not partake in the narrated time. ${ }^{12}$

\footnotetext{
${ }^{10}$ Most influential has been Kullmann (1956, 25-35). Furthermore, cf. e.g. Huxley (1969, 99-112); Baurain (1992); Sbardella (1994); Danek (1998, 247-250). A critical voice against the neoanalytical approach is that of Andersen (2012).

11 I use the term "reader" for practical reasons, but this is also meant to include potential auditors.

12 Cf. Andersen $(2012,138)$ : "Heracles as a father figure and a formidable hero looms large in the horizon."
} 
In what follows, Heracles is being firmly rooted in the epic plupast by different secondary narrators. Dione consoles her daughter Aphrodite who was injured by Diomedes in battle by telling her stories about Hera and Hades who were wounded by Heracles (5.381404). By doing so, she refers to a time gone by: a time when mortals still could (and would) take more liberties with the gods; a time, however, which is still close enough to be remembered and therefore can serve as an exemplum. ${ }^{13}$ The same goes, mutatis mutandis, for the old Nestor who tells Patroclus how Heracles killed all of his brothers in their youth whereas he was the only one who was spared (11.690-693). Again, this story creates both proximity and distance, because it clearly belongs to the epic plupast, but at the same time it is relevant enough to be used as an exemplum for the current generation (and via Nestor it has an obvious link between then and now). Finally, we may also view Athena's mention of Heracles along the same lines (8.357-369): by pointing to the fact that she used to help Heracles during his dodekathlos for the sake of Zeus, she tries to argue that now, Zeus should therefore cease to assist the Achaeans. Again, Heracles is used as an exemplum from the not so distant past that is regarded as relevant for the present.

A story to which allusions are made on several occasions is that of Hesione's rescue from the sea monster sent by Poseidon, Laomedon's break of promise to award Heracles with his immortal horses if he was able to kill the monster, and the subsequent destruction of Troy by Heracles. The story is never recounted in full in the Iliad, but it is evident that Homer "alludes to pieces of a story that he expects his audience to know" (Gantz 1993, 400). ${ }^{14}$ The first destruction of Troy happened as a revenge by Heracles for not being compensated as promised by Laomedon; the second destruction is going to happen as a collective retaliation by the Achaeans for the abduction of Helen through Laomedon's grandson Paris. Thus, a clear parallel is established between the first and the second destruction of Troy. ${ }^{15}$ In other words, the first destruction serves as a prolepsis to the impending second destruction, and consequently, the numerous references to Heracles in the Iliad obtain a collective narrative function, since each mention of Heracles has the potential to invoke this association. Consequently, Heracles and Achilles - the latter being the Iliadic key factor towards the

\footnotetext{
${ }^{13}$ Heracles' divine side is completely suppressed at that moment (cf. Menkes 1978, 13). The motif of Heracles attacking gods can also be found at $O d$. 8.214-225 (on which passage cf. below) and is resumed later by Panyassis: cf. frs. 6, 20, and 21 Matthews = fr. 26 West, with Matthews' $(1974,52-57)$ commentary.

${ }^{14}$ Il. 5.638-642, 5.648-651, 14.250-251, 20.144-148; also 5.263-272 on the immortal horses; cf. Alden (2000, 158-159); Gantz (1993, 400-402); Stafford (2012, 70-72).

${ }^{15}$ It is questionable, though, if a mythological tradition of a First Trojan War existed, as argued by Porter (2014).
} 
capture of Troy (albeit not its actual destroyer) - can be viewed as parallel figures, whereby Heracles serves as a mythical example from the epic plupast. ${ }^{16}$ Interestingly, Achilles puts himself into a parallel line with Heracles when he consoles his mother Thetis with reference to what Edwards $(1991,162)$ calls the "even Herakles died"-topos (Il. 18.117-121):

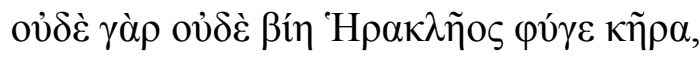

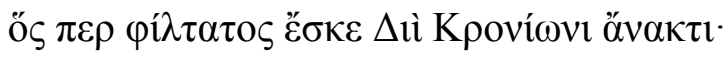

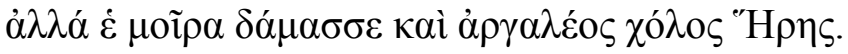

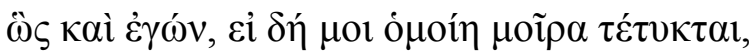

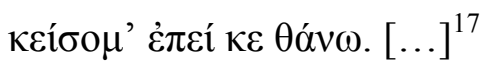

Shortly afterwards, Agamemnon uses the same equation for his own purposes where the story of Eurystheus' premature birth is used as mythical exemplum to demonstrate the power of ă $\tau$. By doing so, Agamemnon attempts to justify his abusive behaviour towards Achillles by attributing it to a moment of infatuation. However, there is irony in this parallelization: Agamemnon happens to be in a formally superior position over Achilles, but the latter possesses far superior physical strength; the same is the case with Eurystheus and Heracles. Thus, by citing the Eurystheus-and-Heracles-story as an example to illustrate his ót Agamemnon ironically (albeit inadvertently) puts himself into the same inferior position as Eurystheus. In addition to this, the equation between Achilles and Heracles is also reconfirmed. $^{18}$

\subsection{Heracles in the Odyssey}

Heracles in the Odyssey is both similar to, and different from, his counterpart in the Iliad. He belongs to the same past, but the Heracles references are considerably fewer in the Odyssey as compared to the Iliad, and they are of a decidedly different quality:

8.214-225: Odysseus at the court of the Phaeacians mentions Heracles as an example of an excellent archer from a previous generation who even challenged the gods and with whom he would not be able to compete.

\footnotetext{
${ }^{16}$ On the parallels between Heracles and Achilles in the Iliad cf. in detail Menkes (1978, 73-117, 148).

17 "For, not even the powerful Heracles escaped the doom [of death], / although he was dearest to king Zeus, the son of Cronus; / but destiny and the painful wrath of Hera overcame him. / Such I too, if a similar destiny is meant for me, / will be lying there once I've died."

${ }^{18}$ Cf. Davidson (1980, 200). For a different opinion, cf. Galinsky (1972, 9), who regards Achilles and Heracles as two contrastive characters.
} 
11.266-270: Odysseus in the Underworld catches a glimpse of Heracles' mother Alcmene and his wife Megara.

11.601-627: Odysseus in the Underworld meets Heracles' "shadow" ( $\varepsilon$ i $\delta \omega \lambda o v)$ (Heracles himself is in the Olympus, deified). He is described as an intimidating archer, and his quiver mirrors his nature as a fierce warrior. Heracles then talks to Odysseus and mentions his troublesome labours before he vanishes again.

21.11-41: The primary narrator recounts the story of Iphitus from whom Odysseus once received his bow as a host gift. Heracles killed Iphitus and stole his horses.

In the Odyssey, a meeting between Heracles (a figure from the epic plupast) and Odysseus (the protagonist in the narrated time) takes place. This is arguably the most prominent difference as compared to the Iliadic Heracles references. However, it seems significant to note that this meeting takes place in the Underworld (Od. 11.601-627) - that is, despite the fact that the two characters encounter each other, they still belong to different worlds and different time periods. Interestingly, according to $O d$. 11.601-604, Heracles is not only in the Underworld, but he also dwells on Mount Olympus after his apotheosis:

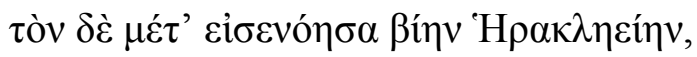

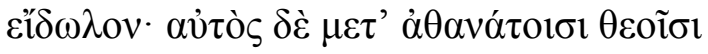

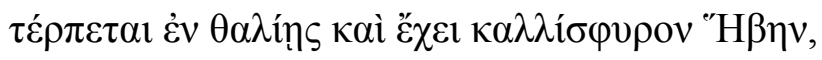

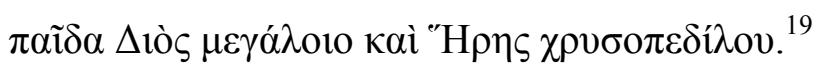

Lines 602-604 have been subject to heavy philological debate since antiquity, and editors have regarded them as a later interpolation, assuming that the apotheosis of Heracles could not be as old as the Odyssey, and that the versions of Heracles' afterlife were, after all, mutually exclusive. ${ }^{20}$ However, the deified Heracles, together with his wife Hebe (viz., personified Youth), can be found in Greek iconography as early as the seventh century B.C. ${ }^{21}$ Furthermore, even if those lines may not be "genuine" in the actual sense of the word, from a reader-response perspective they stand as (and where) they stand - and they do make sense: for, Heracles in the Odyssey no longer serves a proleptic function as he did in the Iliad, and he

\footnotetext{
19 "After this one [= Sisyphus] I saw the powerful Heracles - / [that is to say,] his shadow: he himself is enjoying himself among the immortal gods / at festivities and has Hebe with the fair ankles [as his wife], / a daughter of the great Zeus and of Hera with the golden shoes."

${ }^{20}$ Cf. e.g. Rohde (1895, 625-627). For further references, cf. Matijević (2015, 26-27 n.2); Alden (2017, 61 n.195).

${ }^{21}$ Cf. Burkert $(2005,403)$ (LIMC V.1 s.v. "Herakles”, n. 3331).
} 
does, arguably, not serve any comparable function at all in relation to the main narrative. This lack (or, rather, loss) of function may be reflected in the fact that he dwells both in the Underworld and in Heaven, but not on Earth. Unlike Galinksy (1972, 12), I would therefore not claim that Homer "risked considerable clumsiness in making Odysseus and Herakles meet"; rather, I argue that the simultaneous presence of Heracles in the Underworld and in Heaven be read as a metapoetic hint which suggests that he has been expelled from the "here and now" and thus should be unwritten from epic memory. In contrast to the narrator of the Iliad, whose goal it is to constantly recall Heracles in the reader's memory, the narrator of the Odyssey seems to suggest that Heracles should instead be forgotten.

Two other passages in the Odyssey include an external analepsis to Heracles in the Iliadic style. Both passages emphasize the darker side of Heracles: his antagonistic, perhaps even hubristic behaviour towards the gods at 8.214-225, and his massive disregard of the hospitality right, along with the brutal killing of Iphitus, at 21.11-41. The former passage is relevant from an intertextual perspective since it confirms Heracles' ability to challenge the gods as established at Il. 5.381-404 (but without the paradigmatic function that the Iliadic passage displays [cf. above]). ${ }^{22}$ The latter was rightly called by Galinsky $(1972,12)$ "one of the most devastating indictments of Herakles in literature". However, scholars disagree as to how to interpret this passage, and how it should be understood in connection with the main narrative. Crissy $(1997,53)$ argues that Heracles and Odysseus be read as parallel figures, whereby Heracles would "serve as a reminder of the negative side of Odysseus' triumph", "project[ing] the tone and nature of the oncoming attack" (viz., Odysseus slaughter of the suitors at Ithace). However, this interpretation ignores the fact that Heracles kills Iphitus for mere avarice, whereas the killing of the suitors is a just retaliation. Rather, Heracles is a parallel figure to the suitors, since they both disregard and spurn the hospitality right. ${ }^{23}$ However, he does perhaps not so much simply foreshadow the forthcoming massacre at the court of Ithaca, but he stands prototypically as a representative of a barbarian stage of development. Thus, the passage demonstrates the immense cultural distance between the past of Heracles and the present of Odysseus; in Galinsky's $(1972,10)$ words: "The Odyssey belongs to a more advanced stage of civilization than the Iliad; it extols the intellectual achievement of its hero and the virtues of the finishing school [...] rather than the battlefield. To that world Herakles, at worst, seemed like a barbarous caveman [...]."

\footnotetext{
${ }^{22}$ I owe this point to Anastasia Maravela. Cf. also Danek (1998, 153).

23 Along those lines, cf. also Galinsky $(1972,12)$.
} 


\section{Heracles in Apollonius of Rhodes' Argonautica}

Several centuries after Homer, Apollonius of Rhodes wrote his Argonautica - a story that lies, chronologically, one to two generations before the Trojan War and thus falls within Heracles' lifetime and prime. Therefore, Heracles is introduced into the expedition of the Argonauts as one of their participants but quits the diegetic level again as early as the end of Book 1 . However, on a metadiegetic level, his memory is kept alive throughout the rest of the narrative until the Argonauts almost meet him again and fail to reunite with him only by a narrow margin at the end of Book 4. Again, to begin with, a list is provided for an overview:

1.122-132: Heracles is part of the team of the Argonauts, which he joins while pursuing his dodekathlos, carrying the Erymanthian Boar (task n. 4) on his shoulders. He is accompanied by his loverboy Hylas.

1.195-198: Heracles is briefly mentioned in connection with Meleager, another Argonaut.

1.332-349: Heracles is elected by the Argonauts as their leader. However, he rejects and instead suggests Jason, who is then elected.

1.394-400: The heavy Heracles and his equally heavy sidekick Ancaeus are placed in the middle of the Argo in order to prevent the ship from sinking.

1.425-431: Heracles and Ancaeus slaughter two oxen as an offering to Apollo.

1.531-533: A short, burlesque reference back to Heracles and Ancaeus sitting in the middle of the Argo, Heracles having placed his club next to himself.

1.850-878: Heracles is among the few who does not take the opportunity to have fun and sex with the women on the isle of Lemnos. Instead, he holds an invective against Jason and exhorts the Argonauts to sail ahead.

1.989-997: Heracles kills several of the Earthborn in Cyzicus during a battle.

1.1040-1041: Heracles kills two combatants in the Argonauts' nocturnal battle against the Doliones.

1.1159-1357: The Hylas episode and Heracles' subsequent abandonment. ${ }^{24}$ Since he has been rowing so fiercely, Heracles breaks his rudder. He refuses to eat and rest and instead explores the forest in order to find a suitable tree to timber a new oar. In

\footnotetext{
${ }^{24}$ The same episode is treated by Theocritus in Idyll 13, and the question of priority between Apollonius and Theocritus has long been a matter of hot philological debate, without a solution ever being reached. For a survey of scholarship, cf. e.g. Mauerhofer (2004, 103-112); Köhnken ( ${ }^{2} 2008$, 83-93); Glei ( $\left.{ }^{2} 2008,22-23\right)$. I consider the question to be irrelevant for our purposes.
} 
the meantime, Hylas is looking for a spring with fresh water; he finds a beautiful place where one of the naiads falls in love with him and captures him. Polyphemus (another Argonaut) hears Hylas cry and alerts Heracles; Heracles becomes frenzied and starts looking for Hylas. In the meantime, the other Argonauts - unaware of what has been happening - take the opportunity of a fresh breeze to set sail. They forget about Heracles and do not notice his absence before next morning. An argument about whether or not to retrieve him is interrupted by the sea god Glaucus who announces that it is Heracles' destiny not to accompany them any further.

2.144-154: The Argonauts reminisce about Heracles after the battle against the Bebryces.

2.762-795: Jason renarrates their previous adventures to Lycus, at whose place the Argonauts are guests. He also briefly mentions the abandonment of Heracles (Jason's narration is reported in short, indirect speech by the primary narrator). Lycus is deeply moved and therefore in turn recounts how he recently met Heracles (who was on his way to fetch the girdle of the Amazon Hippolyta [task n. 9]) and how Heracles helped him to defeat some of his enemies.

2.911-914: The Argonauts pass by the grave of Sthenelus, who had been a war companion of Heracles in the Amazonomachia.

2.955-971: The Argonauts meet the three sons of Deimachus, who also had been companions of Heracles in the Amazonomachia, and take them aboard. They pass by the Cap of the Amazons and are thus reminded of Heracles and the Amazonomachia once more.

2.1047-1059: Amphidamas mentions Heracles' technique of hunting down and killing the Stymphalian birds (task n. 6) as a model of how to cope with the birds of Ares.

3.1231-1234: The arming of Aietes includes an auctorial remark saying that Heracles would have been the only one who would have been able to carry Aietes' lance.

4.537-543: The Argonauts are sojourning with the Hylleans, who trace themselves back to Hyllos, a son of Heracles.

4.1393-1482: During their journey through Libya, the Argonauts are looking for water and meet the Hesperides, whom Heracles just passed by the day before. Aigle one of the Hesperides, now transformed into a tree - recounts how Heracles (whom she in fact does not know) came along, stole their apples and destroyed their dwelling. 
The Argonauts, in turn, find a spring which Heracles knocked out of a rock the day before; thus, Heracles (indirectly) saves the Argonauts' lives. They now finally decide to look for him, but only the Argonaut Lynceus ("Lynx-eyed") is able to catch a last glimpse of him from afar before he vanishes.

Most scholars interpret the Apollonian Heracles as a foil to Jason, the weak "post-Homeric" anti-hero who is repeatedly characterized by the primary narrator as $\dot{\alpha} \mu \eta \dot{\chi} \chi \alpha v o \varsigma$ ("resourceless, helpless, incapable"). ${ }^{25}$ In contrast, Heracles is regarded as the traditional type of the firm and persevering hero from the ancient times who, after having mentored Jason for a while, needs to leave the diegesis and, in so doing, withdraws from a world that is no longer his. Consequently, in order to facilitate Heracles' premature withdrawal, he "is presented as distinctively disruptive, never fully assimilated into the crew" (Papadimitropoulos 2006, 42). ${ }^{26}$ Indeed, the antithetic and at times even hostile relation between Heracles and Jason is obvious. It is programmatically introduced as a motif at the beginning when the leader of the Argonauts is elected: Jason asks the others to "chose the best, without being considerate, / as chief" ( Heracles is elected. Heracles, however, rejects the offer and instead suggests Jason, who then is appointed without a dissentient vote. This scene clearly serves to demonstrate Heracles' undisputed authority: not only is he elected, but he also has the power to decline and to pass on the function; Jason, in turn, is not elected because of his abilities, but by Heracles' appointment - he becomes, as Köhnken $(2003,21)$ aptly phrases it, "the leader of the Argonauts' expedition by grace of Heracles". ${ }^{28}$

Another example that illustrates this antithesis can be found in the context of the episode on the isle of Lemnos (1.609-909) where most of the Argonauts, including Jason, are enjoying themselves and feasting with the women who previously killed all their men but now

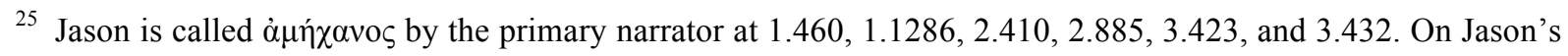
$\grave{\alpha} \mu \eta \chi \alpha v^{\prime} \eta$, cf. e.g. Hunter (1988) and Jackson (1992); Pietsch (1999, 100 n.3) for further references. However, more positive evaluations of Jason's character also exist; cf. e.g. Cuypers $(1997,6)$, who maintains that the Apollonian Jason "possesses the skills which are associated with civilisation, and which enable one to function within society"; according to Heerink $(2015,22)$, he "fall[s] short with regard to the heroic credentials of his Homeric predecessors", but "has other qualities, such as his beauty and his intelligence".

${ }^{26}$ For a summary of this communis opinio including references to further critical reading, cf. Carspecken (1952, 120); Pietsch (1999, 100 nn.3-4); Glei (22008, 6-12).

${ }^{27} \dot{\alpha} \varphi \varepsilon 1 \delta \eta \dot{\sigma} \alpha \nu \tau \varepsilon \varsigma$ ("without being considerate”): that is, without taking into consideration anyone's wishes and preferences, the only factor being who really is the best.

28 “'JJason wird zum] Führer der Argonautenexpedition von Herakles' Gnaden [...]."
} 
regret their action. Heracles, however, remains abstentious, and after having tolerated the debauchery for a few days, he finally becomes furious and fiercely exhorts the Argonauts to sail ahead. He finishes his speech with a brief, but poignant invective against Jason (1.872874):

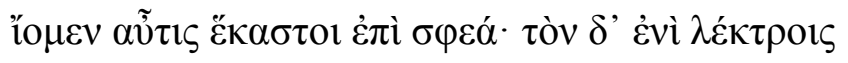

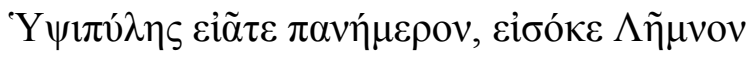

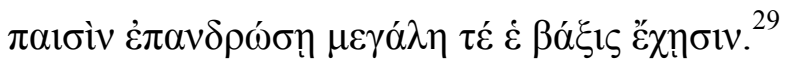

With these words, Heracles does not merely insult Jason, but he establishes an intertextual link to the paradigmatic womanizer in Greek epic, Paris: in the Iliad Hector scolds Paris for

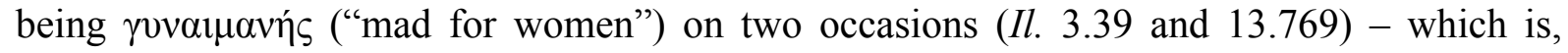
evidently, a heavy term of abuse against a hero. By doing so, Heracles combines several of his typologies. First, he indirectly puts himself into the role of Hector and thus appears as an epic character. ${ }^{30}$ Secondly, he also hints at his role of the Hercules Stoicus who is dutyconscious and abstentious. Thirdly, simultaneously the choleric Hercules furens-type is also insinuated since Heracles is enraged - so much so that no one dares to look into his eyes, but instead everyone immediately obeys him (1.875-878):

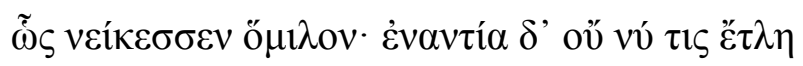

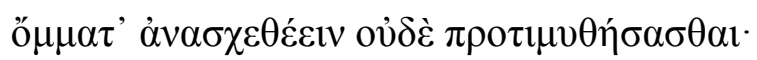

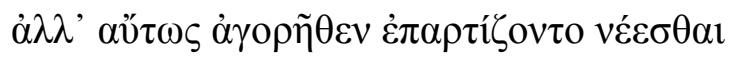

$\sigma \pi \varepsilon \rho \chi \rho_{\mu} \mu \varepsilon v o 1 .[\ldots]^{31}$

This passage clearly demonstrates how the Apollonian Heracles is constructed, in a virtually programmatic manner, as an inconsistent, even self-contradictory character. By no means does he constitute a coherent, round figure as several scholars have maintained, such as Hübscher $(1940,42)$, who claimed that "Apollonius [...] made an effort to provide us with a

\footnotetext{
29 "Let's go, each one onto his place! But the one over there [= Jason], leave him / in bed with Hypsipyle all day long, until he has / populated Lemnos with male children and gets great glory [out of that]."

${ }^{30}$ The decidedly epic side of Heracles is, however, marginal in the Argonautica; it appears only briefly at 1.1040-1041 when he kills two combatants in the nocturnal battle against the Doliones. Heracles is thus by no means "the poem's most obvious symbol of conventional heroism" (Farrell 1995) or "the archetypal hero, possessed of heroic-epic qualities that are constantly associated with Homeric heroism" (Heerink 2015, 25).

31 "Thus he scolded the crowd; and no one dared / to lift up their eyes against him or to talk to him - / but directly from the assembly they prepared themselves to travel along / in a hurry. [...]"
} 
comprehensive and coherent picture of the hero", ${ }^{32}$ or Pike (1980, 44 n.11), whose statement that "Apollonius' Heracles [...] is [...] slightly comic and incongruous but basically dangerous and destructive" reveals an urge to reconcile the different traits and types of Heracles into something that at the end of the day could count as a coherent character. On the contrary, it can be shown that the Apollonian narrator operates precisely on the basis of the complexity, the ambivalence and the inconsistency of Heracles' character, and that these features in turn are employed for metapoetic purposes. In what follows, this metapoetic level will be traced and discussed further.

A large number of the Heracles references in the Argonautica concern the dodekathlos. With this focus, the topos of Heracles the "civilizer" and saviour of mankind is invoked. However, many of these instances are comically inversed, since in many of them their burlesque side is emphasized to the detriment of their heroic qualities - such as on the occasion of Heracles' first appearance that includes a vivid description of how he arrives in the nick of time with the Erymanthian Boar on his shoulders, panting and sweating (1.122132). This description introduces Heracles as the type of the athletic, but intellectually limited strongman hero - a motif that recurs, for example, when he breaks his oar out of overzeal (1.1164-1171), not realizing what has happened and "looking around puzzled" ( $\pi \alpha \pi \tau \alpha i v \omega v$,

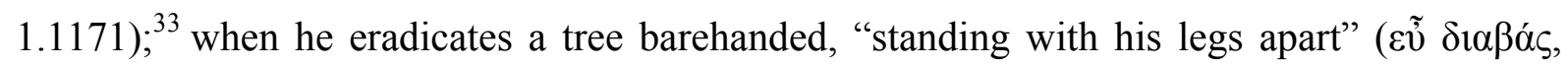
1.1199); and when it is reported that he was able to knock a water spring out of a rock with only one foot (4.1444-1446). Furthermore, on several occasions he is depicted as having his heavy club with $\operatorname{him}(1.427,1.532,1.1196,1.1206,2.149,4.1439)$ - a weapon that is clearly not worthy of an epic hero but, rather, serves to stress Heracles' uncouth nature.

Akin to the strongman hero motif is the theme of the intoxicated and gluttonous (and therefore overweight) Heracles, which is at home in comedy and the satyr play and therefore can be typologized as Hercules comicus. This motif is prevalent in an alternative mythological tradition according to which Heracles was denied access to the Argo because of his overweight. ${ }^{34}$ Obviously, Apollonius does not follow this tradition, but he alludes to it in

\footnotetext{
32 “Apollonios [...] hat sich [...] bemüht, uns ein möglichst inhaltsreiches, geschlossenes Bild des Helden zu geben."

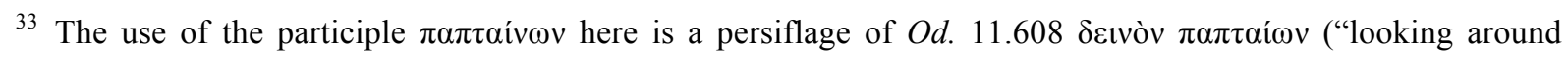
ghastly"); cf. Pike (1980, 44 n.10).

${ }^{34}$ Cf. e.g. Schol. Arg. 1.1289-1291a, p. 116.14-18 Wendel; Antimachus fr. 58 Wyss = fr. 69 Matthews; Pherekydes FGrHist 3 F 111 (= Apollod. 1.188). According to yet another tradition, he was denied access to the Argo because of his immense physical strength (cf. e.g. Arist. Polit. 1284a 22-25), which makes sense because muscular mass is heavier than fat.
} 
two passages (1.394-400 and 1.531-533). Furthermore, in the context of the Hesperides episode the comic Heracles resonates again when it is reported that he drinks to repletion, lying on the ground in front of a water spring (4.1447-1449). Here, in fact, the motif of the comic Heracles who is fond of drinking is combined with the opposite type of the Stoic Heracles, since he does drink a lot - but only water, not alcohol. ${ }^{35}$ Thus, at the end of the Argonautica two different Heraclesses are combined into one simultaneously.

Indeed, the Hesperides episode may be viewed as the key to the understanding of the Apollonian Heracles. Here again, Heracles is, first and foremost, portrayed negatively as a violent and ruthless Hercules furens who pursues his dodekathlos regardless of the consequences. First, the primary narrator gives a detailed account of the current situation that is focalized through the perception of the Argonauts (4.1393-1407): desperately looking for water, the Argonauts arrive at the garden of the Hesperides where Heracles passed by just the day before to steal the golden apples. The traces of his destructive action are still clearly visible: Ladon, the guardian snake, is lying on the ground, struck down by Heracles' poisonous arrows, tormented by flies drying on his wounds, wincing from pain; and the Hesperides are lamenting his loss in their distress. When the Argonauts approach them, they suddenly dissolve into dust; Orpheus (another Argonaut) interprets this as a sign of their apotheosis and enquires where they can find water (4.1408-1421). ${ }^{36}$ Thereupon the Hesperides rematerialize in the form of trees (4.1422-1430), and one of them, Aigle, tells what has happened (1432-1449). Let us look at the first part of her speech (4.1432-1440):

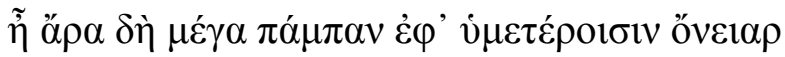

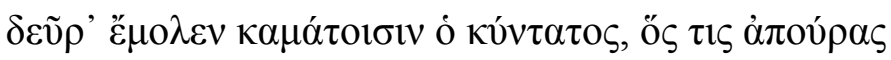

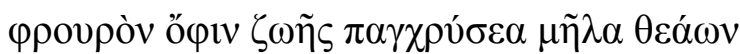

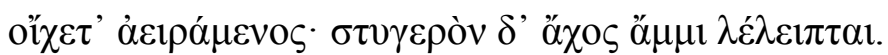

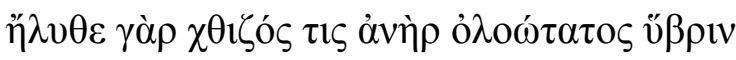

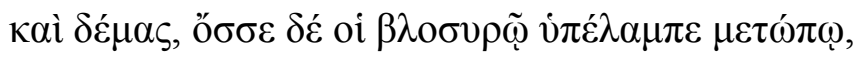

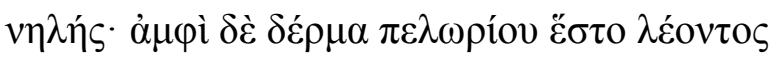

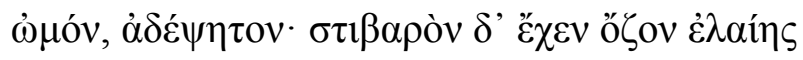

\footnotetext{
35 There existed the idea that excessive consumption of water could lead to intoxication, too (cf. Diod. 3.17.5.), which may be in the background here. The idea of the Apollonian Heracles as a Stoic is emphasized by Fränkel $(1968,115,143)$.

${ }^{36}$ On the much-discussed role of Orpheus in the Argonautica, cf. e.g. Busch (1993); Cuypers (2004, 58-60) (with 60 n.30 for further references); Klooster (2011) 75-87.
} 


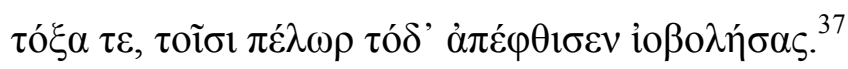

With a mixture of anger, embitterment, and sarcasm, ${ }^{38}$ Aigle recounts the recent incident with

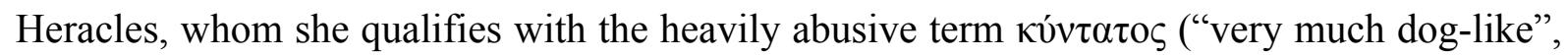
line 1433). Most interesting, however, is the fact that she does not actually seem to know who

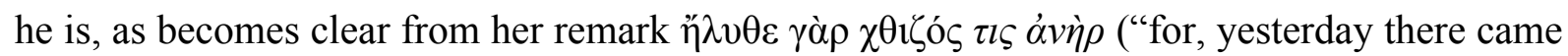
such a man", line 1436). The Argonauts, on the other hand, of course recognize him instantly from Aigle's narration and subsequently attempt to find him. For them, he is a saviour because he saves them from dying of thirst thanks to the water spring which he knocked out of a rock the day before (4.1450-1460).

The last-discussed passage thus combines two completely different views on Heracles, one that is utterly negative and one that is overly positive. In other words, the passage opens up for the juxtaposition of differing perspectives and unfamiliar views, for which the ambiguous and contradictory nature of Heracles' character appears to be predestined. Unlike anyone else in the world, Aigle does not know Heracles. Therefore she might be interpreted as a model reader of the Argonautica, a model reader who takes the polyvalence and ambiguity of the Heracles figure as a starting point for a completely different perception and interpretation of Heracles as opposed to the Argonauts. The Argonauts, in turn, may be seen as representing the mainstream reader. Apollonius clearly exploits the multifaceted and in large parts contradictory nature of Heracles' character to the utmost; as argued before, trying to reconcile the different traits and types of Heracles into a coherent and homogeneous character, as some scholars have done, would be completely mistaken.

The multidimensionality and inherent inconsistency of Heracles' character, culminating in the opposing focalization through Aigle and through the Argonauts, can also be transferred onto the level of narration and narrative strategies. For Heracles, the Argonauts' expedition is not much more than an interlude that interrupts his main assignment, the dodekathlos, only for a short period. After he has left the diegesis, the dodekathlos continues in the background, as a parallel action to the voyage of the Argonauts, and the

\footnotetext{
37 "Truly then, as a very great help for your strains / he came hither, the very much dog-like, who deprived / the guardian snake of her life, took away the golden apples of the goddesses / and went off again - but to us [nothing but] odious pain has been left. / For, yesterday there came such a man, abominable in his outrageousness / and his appearance, and his eyes were sparking below his ferocious forehead - / the merciless! And around his shoulders he was wearing the skin of a giant lion, / an untanned one; and he was holding the hefty bough of an olive tree / and a bow, with which he shot his arrows against this beast here [= Ladon] and killed it."

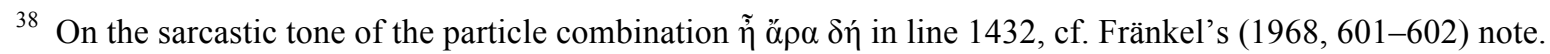


numerous allusions and references to Heracles throughout Books 2 and 4 (with one exception at 3.1231-1234, he is conspicuously absent from Book 3) make sure that his memory is kept alive, ${ }^{39}$ both innerfictionally (viz., for the Argonauts) and extrafictionally (for the readers). I would like to suggest calling this literary phenomenon a narrative palimpsest. As is the case with a manuscript palimpsest where the abraded text never completely vanishes, but can be made visible again, here too some sort of Heracleis comes to the fore as a parallel narrative behind the main story, the Argonautic quest. Again, it is not a coincidence that Heracles was chosen to achieve this end. As was pointed out above, there existed also mythological traditions according to which Heracles was denied access to the Argo because of his overweight. ${ }^{40}$ In contrast to these, we can also find traces of alternative versions of the Argonauts' expedition according to which Heracles was, and remained, their leader throughout. ${ }^{41}$ The primary narrator clearly does credit to - and plays on - all these traditions by introducing Heracles into the diegesis, but making him leave early; by having him elected as the leader of the expedition, but making him decline; and by ironically alluding to his overweight that could potentially cause problems on the Argo. By way of these allusions, the narrator does not only hint at a Heracles epos as a potential option, but he ultimately also invites the reader, on a metapoetic level, to reflect on what the Argonautica itself may have looked like depending on the presence - or absence - of Heracles.

\section{Conclusion}

In the Homeric epics, Heracles belongs to an earlier generation of heroes; he is still close enough to be vividly remembered and referenced both by the primary narrator and by various secondary narrators; but at the same time he is already remote enough to be considered a model (or non-model) from a relatively (but not too) distant past. The numerous references to Heracles dispersed throughout the Iliad fulfil a proleptic function in the sense that Heracles' role as the first destroyer of Troy foreshadows the impending second, final, destruction of the city. The Odyssey, in turn, unwrites Heracles from epic memory by presenting him as an element of a cruel and barbarian stage of humanity, and by relegating him into the Underworld and into Heaven simultaneously. Apollonius of Rhodes, then, works on the basis

\footnotetext{
${ }^{39}$ Based on an analysis of Heracles in Book 2, Philbrick (2011) suggests four categories of Heracles references in the Argonautica: "explicit mention", "verbal echo", "extrapolative allusion”, and "geographic reference".

${ }^{40}$ Cf. above with n. 34 .

${ }^{41}$ Cf. e.g. Dionysius Scytobrachion fr. 15a, p. 146.8 Rusten; Diod. 4.41.3.
} 
of the ambiguous and contradictory nature of Heracles' character, and on the different types and typologies connected to him. Essentially, Heracles' presence in the Argonautica (and his later absence) can be interpreted on a metapoetic level. First, the juxtaposition of different Heraclesses, as well as different focalizations of the same Heracles, open new perspectives on a centuries-old, transtextual character inherited from the archaic epics. Secondly, Heracles' dodekathlos is inscribed as a narrative palimpsest behind the main narrative, the voyage of the Argonauts; thus, the reader is invited to reflect on potentially alternative narrative strategies and contents. Thirdly, Apollonius interweaves his narration with various mythological traditions about Heracles' role in the Argonautic expedition by way of repeated allusions.

The Homeric Heracles, as a character from the epic plupast, fulfils a proleptic function in the Iliad and becomes virtually a shadow in the Odyssey. In the main narrative, he does not act as a character, but as a paradigm. Apollonius' most important innovation is that he takes Heracles out of this shadow and transfers him onto the diegetic level. In doing so, he is able to benefit from the hero's multidimensionality by functionalizing the different Heraclean types and typologies. In addition to this, when he has Heracles leave the diegetic level prematurely, he redefines him in a Homeric sense - that is, by using him in a way that is, again, more strongly paradigmatic. Therefore, in the Argonautica Heracles is a transtextual character not only with regard to its intertextuality with the Homeric Heraclesses, but also intratextually. Heracles wanders diachronically through the history of epic poetry, but he also wanders synchronically through the Argonautica - in a concrete and in a metaphoric sense.

\section{Acknowledgements}

This article is the heavily condensed version of three chapters from my study Herakles im griechischen Epos: Studien zur Narrativität und Poetizität eines Helden (= Bär 2018). Parts of the section on the Argonautica were also published earlier (in different form and format) in the journal Nexus (= Bär 2016/17). I would like to thank the participants at the Oslo Conference "Narratology and Intertextuality: New Perspectives on Greek Epic from Homer to Tzetzes" in June 2016, the participants at the Oslo Reading Circle "Literature, Cognition and Emotion" in October 2018, as well as Øivind Andersen, Anastasia Maravela, Rolf Reber and Sofia Heim for important and helpful feedback on earlier versions. Some preliminary research that led to the results presented here was already carried out during my postdoctoral period in 2012/13 generously funded by the University of Zurich. Finally, I am greatly indebted to Winnie Joanna Greenwood Ormerod for her invaluable help with my English. 


\section{Abstract and Keywords}

This article analyses and discusses the references to the Greek hero and demigod Heracles as they appear in the Homeric epics and in Apollonius of Rhodes' Argonautica. Methodologically, it is based on narratological character analysis in a diachronic perspective, and with a cognitive take. It is demonstrated that Heracles serves specific narrative and metapoetic purposes in all the three epics concerned. In the Iliad, by way of several external analepses he fulfils a proleptic function in his role as the first destroyer of Troy, foreshadowing the ultimate destruction of the city. The Odyssey, in turn, attempts to unwrite Heracles from the epic memory by condemning him into the Underworld and into Heaven, and by emphasizing his barbarian nature. Finally, in the Argonautica Heracles is first present, then absent from the main narrative, and on a metapoetic level he is used as a means of reflecting alternative narrative strategies and contents. In sum, it can be demonstrated that the Heracles figure is particularly apt to serve all these narrative and metapoetic ends because of its decidedly multifaceted, contradictory, and transtextual nature.

Keywords: Heracles; Homer; Iliad; Odyssey; Apollonius of Rhodes; Argonautica; narratological character analysis; transtextual character; diachronic narratology; cognitive criticism; metapoetics; epic plupast; epic memory; narrative palimpsest.

\section{References}

Aldama, Frederick Luis. 2015. "The Science of Storytelling: Perspectives from Cognitive Science, Neuroscience, and the Humanities." Projections 9 (1): 80-95.

Alden, Maureen. 2000. Homer Beside Himself. Para-Narratives in the Iliad. Oxford: Oxford University Press.

Alden, Maureen. 2017. Para-Narratives in the Odyssey: Stories in the Frame. Oxford: Oxford University Press.

Andersen, Øivind. 2012. "Older heroes and earlier poems: the case of Heracles in the Odyssey." In Relative Chronology in Early Greek Epic Poetry, edited by Øivind Andersen and Dag T.T. Haug, 138-151. Cambridge: Cambridge University Press.

Bal, Mieke. 2009. Introduction to the Theory of Narrative. 3rd edition Toronto, Buffalo and London: University of Toronto Press.

Bär, Silvio. 2016/17. "Erzählen, wo es nichts zu erzählen gibt? Herakles bei Apollonios Rhodios, der narrative Palimpsest und die Widerspruchsfähigkeit des Mythos.” Nexus: 
Studentische Zeitschrift des Seminars für Klassische Philologie an der Ruhr-Universität Bochum 4: 6-8.

Bär, Silvio. 2018. Herakles im griechischen Epos: Studien zur Narrativität und Poetizität eines Helden. Stuttgart: Franz Steiner.

Baurain, Claude. 1992. "Héraclès dans l'épopée homérique." In Héraclès: D’une rive à l'autre de la méditerranée. Bilan et perspectives, edited by Corinne Bonnet and Colette Jourdain-Annequin, 67-109. Brussels and Rome: Institut Historique Belge de Rome.

Bruhn, Mark J. and Donald R. Wehrs (eds.). 2014. Cognition, Literature, and History. New York and London: Routledge.

Burke, Michael and Emily T. Troscianko (eds.). 2017. Cognitive Literary Science: Dialogues between Literature and Science. Oxford: Oxford University Press.

Burkert, Walter. 2005. "Vergöttlichung von Menschen in der griechisch-römischen Antike." In Grenzen des Menschseins: Probleme einer Definition des Menschlichen, edited by Justin Stagl and Wolfgang Reinhard, 401-419. Vienna, Cologne and Weimar: Böhlau.

Burkert, Walter. 2011. Griechische Religion der archaischen und klassischen Epoche. 2nd edition Stuttgart: Kohlhammer.

Busch, Stephan. 1993. “Orpheus bei Apollonios Rhodios.” Hermes 121 (3): 301-324.

Carspecken, John Frederick. 1952. "Apollonius Rhodius and the Homeric Epic." Yale Classical Studies 13: 33-143.

Cave, Terence. 2016. Thinking with Literature: Towards a Cognitive Criticism. Oxford: Oxford University Press.

Crissy, Katherine. 1997. "Herakles, Odysseus, and the Bow: Odyssey 21.11-41." Classical Journal 93 (1): 41-53.

Cuypers, Martijn P. 1997. Apollonius Rhodius Argonautica 2.1-310: A Commentary. Leiden: unpublished $\mathrm{PhD}$ thesis.

Cuypers, Martijn P. 2004. “Apollonius of Rhodes.” In Narrators, Narratees, and Narratives in Ancient Greek Literature, edited by Irene J.F. de Jong, René Nünlist and Angus Bowie, 43-62. Leiden and Boston: Brill.

Danek, Georg. 1998. Epos und Zitat: Studien zu den Quellen der Odyssee. Vienna: Verlag der Österreichischen Akademie der Wissenschaften.

Davidson, Olga Merck. 1980. "Indo-European Dimensions of Herakles in Iliad 19.95-133." Arethusa 13 (2): 197-202. 
De Temmerman, Koen. 2014. Crafting Characters: Heroes and Heroines in the Ancient Greek Novel. Oxford: Oxford University Press.

De Temmerman, Koen and Evert van Emde Boas (eds.). 2017a. Characterization in Ancient Greek Literature. Leiden and Boston: Brill.

De Temmerman, Koen and Evert van Emde Boas. 2017b. "Character and Characterization in Ancient Greek Literature: An Introduction.” In Characterization in Ancient Greek Literature, edited by Koen De Temmerman and Evert van Emde Boas, 1-23. Leiden and Boston: Brill.

Edwards, Mark W. 1991. The Iliad: A Commentary. Vol. 5 (Books 17-20). Cambridge: Cambridge University Press.

Farrell, Joseph. 1993. Review of The Best of the Argonauts: The Redefinition of the Epic Hero in Book 1 of Apollonius's Argonautica, by James J. Clauss. Bryn Mawr Classical $\begin{array}{lllll}\text { Review } & 95.06 .04 & \text { Accessed } & 13 & \text { May }\end{array}$ http://bmcr.brynmawr.edu/1995/95.06.04.html.

Feeney, Denis C. 1991. The Gods in Epic: Poets and Critics of the Classical Tradition. Oxford: Clarendon Press.

Fränkel, Hermann. 1968. Noten zu den Argonautika des Apollonios. Munich: C.H. Beck.

Galinsky, G. Karl. 1972. The Herakles Theme: The Adaptations of the Hero in Literature from Homer to the Twentieth Century. Oxford: Basil Blackwell.

Gantz, Timothy. 1993. Early Greek Myth: A Guide to Literary and Artistic Sources. 2 vols. Baltimore and London: The Johns Hopkins University Press.

Garratt, Peter (ed.). 2016. The Cognitive Humanities: Embodied Mind in Literature and Culture. London: Palgrave Macmillan.

Glei, Reinhold F. 2008. "Outlines of Apollonian Scholarship 1955-1999." In Brill's Companion to Apollonius Rhodius, edited by Theodore D. Papanghelis and Antonios Rengakos, 1-28. 2nd edition Leiden and Boston: Brill.

Grethlein, Jonas. 2012. "Homer and Heroic History." In Greek Notions of the Past in the Archaic and Classical Eras: History without Historians, edited by John Marincola, Lloyd Llewellyn-Jones and Calum Maciver, 14-36. Edinburgh: Edinburgh University Press.

Haubold, Johannes. 2005. "Heracles in the Hesiodic Catalogue of Women." In The Hesiodic Catalogue of Women: Constructions and Reconstructions, edited by Richard Hunter, 85-98. Cambridge: Cambridge University Press. 
Heerink, Mark. 2015. Echoing Hylas: A Study in Hellenistic and Roman Poetics. Madison and London: The University of Wisconsin Press.

Heldmann, Georg. 2000. Märchen und Mythos in der Antike? Versuch einer Standortbestimmung. Munich and Leipzig: K.G. Saur.

Hübscher, Adalgott. 1940. Die Charakteristik der Personen in Apollonios' Argonautika. Freiburg i.Üe.: Paulusdruckerei.

Hunter, Richard. 1988. "Short on Heroics': Jason in the Argonautica." Classical Quarterly 38 (2): 436-453.

Huxley, George L. 1969. Greek Epic Poetry from Eumelos to Panyassis. London: Faber and Faber.

Jackson, Steven. 1992. “Apollonius' Jason: Human Being in an Epic Scenario.” Greece \& Rome 39 (2): 155-162.

Jannidis, Fotis. 2004. Figur und Person: Beitrag zu einer historischen Narratologie. Berlin and New York: Walter de Gruyter.

Kirk, Geoffrey S. 1973. "Methodological reflexions on the myth of Heracles." In Il mito greco: Atti del Convegno Internazionale (Urbino 7-12 maggio 1973), edited by Bruno Gentili and Giuseppe Paioni, 285-297. Rome: Edizioni dell'Ateneo \& Bizzarri.

Klooster, Jacqueline. 2011. Poetry as Window and Mirror: Positioning the Poet in Hellenistic Poetry. Leiden and Boston: Brill.

Köhnken, Adolf. 2003. "Herakles und Orpheus als mythische Referenzfiguren (,Identifikations-' bzw. ,Integrationsfigur') im hellenistischen Epos.” In Literarische Konstituierung von Identifikationsfiguren in der Antike, edited by Barbara Aland, Johannes Hahn and Christian Ronning, 19-27. Tübingen: Mohr Siebeck.

Köhnken, Adolf. 2008. "Hellenistic Chronology: Theocritus, Callimachus, and Apollonius Rhodius." In Brill's Companion to Apollonius Rhodius, edited by Theodore D. Papanghelis and Antonios Rengakos, 73-94. 2nd edition Leiden and Boston: Brill.

Kullmann, Wolfgang. 1956. Das Wirken der Götter in der Ilias: Untersuchungen zur Frage der Entstehung des homerischen ,Götterapparats '. Berlin: Akademie-Verlag.

Lox, Harlinda. 2007. "Starker Hans.” Enzyklopädie des Märchens: Handwörterbuch zur historischen und vergleichenden Erzählforschung, edited by Rolf Wilhelm et al., vol. 12, 1179-1185. Berlin and New York: Walter de Gruyter.

Matijević, Krešimir. 2015. Ursprung und Charakter der homerischen Jenseitsvorstellungen. Paderborn: Ferdinand Schöningh. 
Matthews, Victor J., ed., comm. 1974. Panyassis of Halikarnassos: Text and Commentary. Leiden: Brill.

Mauerhofer, Kenneth. 2004. Der Hylas-Mythos in der antiken Literatur. Munich and Leipzig: K.G. Saur.

Menkes, Marny Sharon. 1978. Herakles in the Homeric Epics. Baltimore: unpublished PhD thesis.

Mueller, Melissa. 2016. "The Disease of Mortality in Hesiod's Theogony: Prometheus, Herakles, and the Invention of Kleos." Ramus 45 (1): 1-17.

Müller-Wood, Anja. 2017. "Cognitive Literary Studies: On Persistent Problems and Plausible Solutions." Journal of Literary Theory 11 (2): 223-239.

Papadimitropoulos, Loukas. 2006. “Alexandrian Adaptations of Heracles’ Myth.” Parnassos 48: 41-68.

Philbrick, Rachel Severynse. 2011. The Ghost of Heracles: The Lost Hero's Haunting of Argonautica 2. Lexington: unpublished MA thesis.

Pietsch, Christian. 1999. Die Argonautika des Apollonios von Rhodos: Untersuchungen zum Problem der einheitlichen Konzeption des Inhalts. Stuttgart: Franz Steiner.

Pike, D.L. 1980. "The Comic Aspects of the Strongman-Hero in Greek Myth." Acta Classica 23: $37-44$.

Porter, Andrew. 2014. "Reconstructing Laomedon's Reign in Homer: Olympiomachia, Poseidon's Wall, and the Earlier Trojan War.” Greek, Roman and Byzantine Studies 54 (4): 507-526.

Prinz, Friedrich. 1974. "Herakles 1." Real-Encyclopädie der classischen Alterthumswissenschaft. Suppl.-vol. XIV: 137-196.

Richardson, Brian. 2010. "Transtextual Characters." In Characters in Fictional Worlds: Understanding Imaginary Beings in Literature, Film, and Other Media, edited by Jens Eder, Fotis Jannidis and Ralf Schneider, 527-541. Berlin and New York: Walter de Gruyter.

Rohde, Erwin. 1895. "Nekyia.” Rheinisches Museum für Philologie 50: 600-635.

Sbardella, Livio. 1994. "Tracce di un epos di Eracle nei poemi omerici." Studi Micenei ed Egeo-Anatolici 33: 145-162.

Stafford, Emma. 2005. "Vice or virtue? Herakles and the art of allegory." In Herakles and Hercules: Exploring a Graeco-Roman Divinity, edited by Louis Rawlings and Hugh Bowden, 71-96. Swansea: The Classical Press of Wales.

Stafford, Emma. 2012. Herakles. London and New York: Routledge. 
Tarán, Leonardo and Dimitri Gutas, eds., comm. 2012. Aristotle Poetics: Editio Maior of the Greek Text with Historical Introductions and Philological Commentaries. Leiden and Boston: Brill.

van Thiel, Helmut, ed. 1991. Homeri Odyssea. Hildesheim, Zurich and New York: Georg Olms.

van Thiel, Helmut, ed. 1996. Homeri Ilias. Hildesheim, Zurich and New York: Georg Olms.

Vian, Francis and Émile Delage, eds., trans., comm. 1974-1981. Apollonios de Rhodes: Argonautiques. 3 vols. Paris: Budé.

Wege, Sophia. 2013. Wahrnehmung - Wiederholung - Vertikalität: Zur Theorie und Praxis der Kognitiven Literaturwissenschaft. Bielefeld: Aisthesis Verlag.

West, Martin L., ed., trans., comm. 2003. Greek Epic Fragments from the Seventh to the Fifth Centuries BC. Cambridge, MA and London: Harvard University Press.

Zunshine, Lisa. 2015. The Oxford Handbook of Cognitive Literary Studies. Oxford: Oxford University Press. 